\title{
Cbz-aminomethylphosphonic acid and its structural variations: synthesis from a common precursor and a stability study
}

\author{
Stamatia Vassiliou \\ Laboratory of Organic Chemistry, Department of Chemistry, University of Athens, \\ Panepistimiopolis, Zografou, 15701 Athens, Greece \\ E-mail: svassiliou@chem.uoa.gr
}

\section{Dedicated to Prof. Pawel Kafarski to honor the achievements of his career}

\begin{abstract}
Cbz-aminomethylphosphonic acid as well as its $\mathrm{P}=\mathrm{S}, \mathrm{P}=\mathrm{Se}$ and $\mathrm{P}-\mathrm{BH}_{3}$ analogs were synthesized using $\mathrm{DMSO} / \mathrm{I}_{2}$ and a three-step, one-pot procedure respectively. In all cases the corresponding Cbz-aminomethylphosphinic acid was the starting material. The latter case, oxidation of the BSA-generated disilylester using elemental sulfur, selenium and $\mathrm{BH}_{3} \cdot \mathrm{Me}_{2} \mathrm{~S}$ followed by methanolysis represents a convenient, high yielding synthetic method for these useful building blocks. The stability of the compounds under several conditions is also discussed.
\end{abstract}

Keywords: Phosphinic acid, phosphonic acid, thiophosphonic acid, selenophosphonic acid, boranephosphonic acid, stability

\section{Introduction}

Recent years have seen a steadily growing family of natural and synthetic biologically active products containing a $\mathrm{P}-\mathrm{C}$ bond that is resistant to cleavage by strong acids and bases and by most enzymes. ${ }^{1}$ Of special interest are phosphonic acid derivatives as stable mimetics of natural phosphates and substrates in the study of biochemical processes. Their physiological activity ranges from herbicidal, plant hormone growth, antibacterial to anticancer, as well as inhibition of enzymes such as phosphatases, glutamine synthetase, cathepsin $\mathrm{C}$ or zinc proteinases. ${ }^{2}$ Fosphomycin is a broad-spectrum antibiotic produced by certain Streptomyces species ${ }^{2}$ at present commercially available under the name Monouril ${ }^{\circledR}$. Additionally, two phosphonic drugs were approved by FDA in recent years: Cidofavir is an injectable, antiviral agent for the treatment of Cytomegalovirus retinitis. Foscavir is an antiviral agent to treat herpes virus diseases (Scheme 1). ${ }^{3}$ In particular, aminophosphonic acids derivatives are isosters of the corresponding amino acids and their synthesis has been reviewed recently. ${ }^{4}$ Among them, $\mathrm{N}$ protected 1- 
aminoalkanephosphonic and phosphinic acids can be ranked amongst the most versatile and relevant building blocks for further phosphorus modifications and chemistry of pseudopeptides. ${ }^{4,5}$

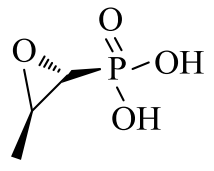

phosphomycin<smiles>Nc1ccn(C[C@H](CO)OCP(=O)(O)O)c(=O)n1</smiles>

cidofavir<smiles>O=C(O)P(=O)(O)O</smiles>

foscavir

\section{Scheme 1}

Recently, two types of phosphonic acid analogs, namely thiophosphonic acids ${ }^{6}$ and boranephosphonic acids ${ }^{7}$ have been introduced in the search for antiviral activity and as phosphatase inhibitors, respectively.

Herein we provide a general synthetic approach to structurally related Cbzaminoalkanephosphonic acids. All compounds were prepared from Cbz-aminomethylphosphinic acid $1 .{ }^{8}$ To date, this is the first report for the sulfur, selenium and borane analogs.

\section{Results and Discussion}

\section{Synthesis}

Oxidation of the $\mathrm{P}-\mathrm{H}$ bond of the Cbz-aminomethylphosphinic acid 1 (Cbz-Gly- $\mathrm{PO}_{2} \mathrm{H}_{2}$, an analog of glycine) was achieved by heating 1 with 1 equiv of DMSO and a catalytic amount of iodine at $60^{\circ} \mathrm{C}$ for $5 \mathrm{~h}$ to yield Cbz-aminomethylphosphonic acid 2. ${ }^{9}$ This method is advantageous in terms of simplicity and high yield given the fact that the synthesis of phosphinic acids is well established and documented. ${ }^{5}$

The protected H-phosphinic derivative $\mathbf{1}$ was then oxidized to the corresponding thiophosphonate under mild conditions. Compound $\mathbf{1}$ was silylated to the protected bis(trimethylsilyl)phosphonite (BTSP) intermediate with $\mathrm{N}, \mathrm{O}$-bis(trimethylsilyl)acetamide (BSA). In the presence of sulfur powder this intermediate was smoothly oxidized to the protected thiophosphonate 3, after methanolysis of the silyl esters. The reaction was carried out at room temperature, under argon, in a total of 1 hour. Compound $\mathbf{3}$ was essentially pure after usual work up, although column chromatography is feasible since this compound is quite less polar compared to its oxygen counterpart 2 . The purity of $\mathbf{3}$ was easily checked by ${ }^{31} \mathrm{P}$ NMR because of the large difference in chemical shifts (77.4 ppm for $\mathbf{3}$ and for $22.3 \mathrm{ppm}$ for $\mathbf{1}$ ). This increase in chemical shift can be attributed to the electron density which is located more on the sulfur bound to phosphorus, compared to oxygen. HPLC is another useful means of checking the purity of this new compound $\left(t_{\mathrm{R}}=17.4 \mathrm{~min}\right.$ for $\mathbf{3}$ and $15.1 \mathrm{~min}$ for 2$)$. This assessment was used to 
check the stability of $\mathbf{3}$ after several weeks of storage at room temperature and in aqueous buffers. Using the SPARC algorithm, ${ }^{10} \mathrm{p} K_{\mathrm{a}}$ of the $-\mathrm{OH}$ groups was calculated (Scheme 2) and the big difference in $\mathrm{p} K_{\mathrm{a} 2}$ (7.43 for $2,3.70$ for $\mathbf{3}$ ) implies a higher acidic character for $\mathbf{3}$ and, given the possible biological impact of such compounds, means that at physiological $\mathrm{pH} 2$ is partially ionized while $\mathbf{3}$ is almost totally deprotonated.
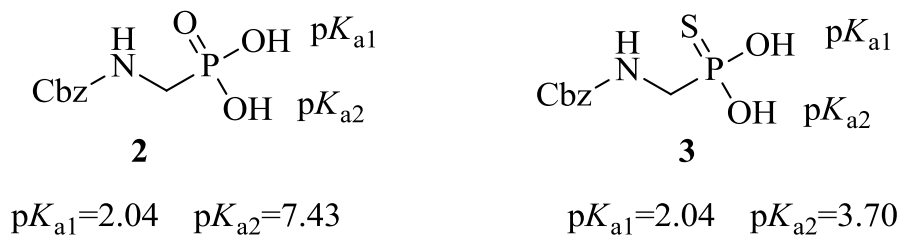

\section{Scheme 2}

Thiophosphonic acid 3 may exist in two tautomeric thiolo $(\mathrm{P}-\mathrm{SH})$ or thiono $(\mathrm{P}=\mathrm{S})$ forms in aqueous solution. Studies indicate that the thiono-thiolo equilibrium lies far on the thiono side in phosphonothioic acids when a carbon-phosphorus bond is present. ${ }^{6}$ In our case, absence of signal in 45-55 ppm region known for thiolo isomers demonstrated that $\mathbf{3}$ does not show thiono-thiolo equilibrium.

Table 1. Synthesis of phosphonic acids $2, \mathbf{3}, \mathbf{4}, \mathbf{5}$, selected IR $v\left(\mathrm{~cm}^{-1}\right)$ and NMR $(\delta$ in ppm), $(J$ in $\mathrm{Hz}$ ) signals, HPLC data

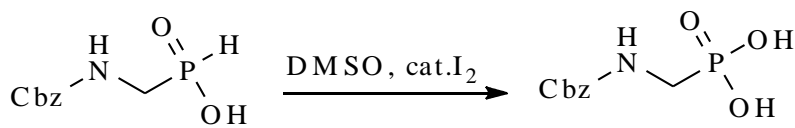

1

2

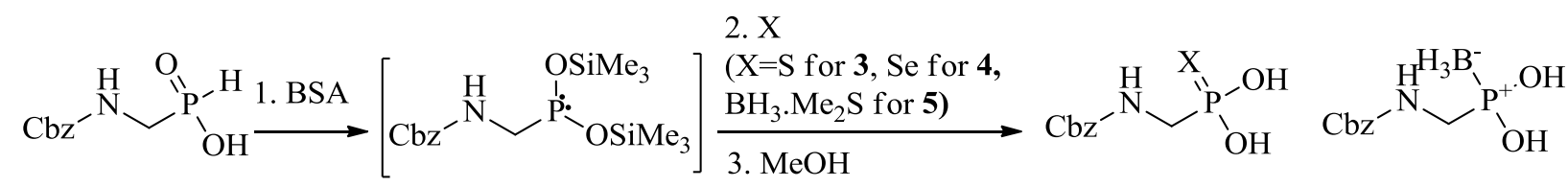

1

\begin{tabular}{|c|c|c|c|c|c|c|}
\hline No & $X$ & $(\text { Yield, } \%)^{\mathrm{a}}$ & $\begin{array}{l}{ }^{31} \mathrm{P} \text { NMR } \\
\delta, \mathrm{ppm}\end{array}$ & $\begin{array}{l}{ }^{13} \mathrm{C} \mathrm{NMR} \\
C H_{2}-\mathrm{P} \\
\delta, \operatorname{ppm}\left({ }^{1} J_{\mathrm{PC}}, \mathrm{Hz}\right)\end{array}$ & $\begin{array}{l}\text { IR } \\
P=X \\
v\left(\mathrm{~cm}^{-1}\right)\end{array}$ & $\begin{array}{l}\mathrm{HPLC}^{\mathrm{b}} \\
t_{\mathrm{R}} \\
(\min )\end{array}$ \\
\hline 2 & $\mathrm{O}$ & 93 & 17.2 & $42.1(94.3)$ & 1223 & 15.1 \\
\hline 3 & $\mathrm{~S}$ & 90 & 77.4 & $46.3(101.2)$ & 632 & 17.4 \\
\hline 4 & $\mathrm{Se}$ & 87 & 76.2 & $49.9(96.0)$ & 570 & 16.1 \\
\hline 5 & $\mathrm{P}-\mathrm{BH}_{3}$ & 91 & 117.6 & $41.0(61.3)$ & 780 & 25.7 \\
\hline
\end{tabular}

${ }^{\mathrm{a}}$ Isolated yields after workup. ${ }^{11 \mathrm{~b}} t_{\mathrm{R}}=$ retention time. Conditions: see experimental part. 
After the successful isolation of the phosphonothioic acid $\mathbf{3}$, it seemed a logical extension to try to prepare the selenium and tellurium analogs.

Following essentially the same experimental part that was applied for $\mathbf{3}$, selenophosphonic acid 4 was obtained in high yield as glassy solid after usual work up. The ${ }^{31} \mathrm{P}$ NMR of 4 displays a sharp peak at $76.2 \mathrm{ppm}$ accompanied by a set of satellites with a ${ }^{31} \mathrm{P}_{-}{ }^{77} \mathrm{Se}$ coupling constant of $537 \mathrm{~Hz}$ which is characteristic of $\mathrm{P}=\mathrm{Se}$ bond although smaller compared to other $\mathrm{P}=\mathrm{Se}$ containing compounds described in the literature. ${ }^{12}$ In the infrared spectra of 4 the $v(\mathrm{P}=\mathrm{Se})$ vibration appears as a medium intensity band at $570 \mathrm{~cm}^{-1}$. The parent ion in the mass spectrum of 4 showed four isotopomeric peaks corresponding to the ${ }^{80} \mathrm{Se},{ }^{78} \mathrm{Se},{ }^{77} \mathrm{Se}$ and ${ }^{76} \mathrm{Se}$ isotopes. Unfortunately, SPARC algorithm Web site was unable to calculate $\mathrm{p} K_{\mathrm{a}}$ of the $-\mathrm{OH}$ for 4 .

On attempted reaction with tellurium, 1 was recovered unchanged. The underlying reasons can be sought in the more metallic properties of tellurium which result in a distinct weakening of covalent bonds. $^{13}$

The downfield shift of $\mathbf{3}$ and $\mathbf{4}$ compared to $\mathbf{2}$ in ${ }^{31} \mathrm{P}$ NMR can be related to some relevant physicochemical properties ${ }^{13}$ of the chalcogen elements oxygen, sulfur, selenium and tellurium which are listed in Scheme 3. From this study, one can see the effects of the lower electronegativity and the greater polarizability of sulfur and selenium compared to oxygen.

\begin{tabular}{|l|l|l|l|l|}
\hline Property & oxygen & sulfur & selenium & tellurium \\
\hline electronegativity & 3.44 & 2.58 & 2.55 & 2.1 \\
\hline covalent radius $(\AA)$ & 0.73 & 1.02 & 1.17 & 1.35 \\
\hline
\end{tabular}

\section{Scheme 3}

The bis(trimethylsilyl)phosphonite intermediate (BTSP), with the free electron pair at phosphorus, is also a suitable donor for the $\mathrm{BH}_{3}$ group introduction. So we next attempted the synthesis of boranephosphonate 5. Indeed, by using two equivalents of $\mathrm{BH}_{3} \mathrm{Me}_{2} \mathrm{~S}$ complex, $\mathbf{5}$ was obtained in high yield and purity with simple workup (Table 1). The infrared spectrum of 5 exhibits a stretching band at $2358 \mathrm{~cm}^{-1}$ corresponding to B-H stretch and absorption at $780 \mathrm{~cm}^{-1}$ associated with the P-B stretch. ${ }^{14}$ The ${ }^{31} \mathrm{P}$ NMR of $\mathbf{5}$ has a doublet with broad peaks (more like a quartet but only the central lines were observed) at $117.6 \mathrm{ppm}$, slightly more downfield compared to $\mathbf{3}$ and $\mathbf{4}$, attributed to the removal of electron density from the P-center to the coordinated borane ${ }^{15}$ which is negatively charged. The boron-phosphorus coupling constant cannot be reliably assessed from the ${ }^{31} \mathrm{P}$ spectra as a result both of the broadness of the peaks and the unusually high instrument gains required to observe the spectra. The $\mathrm{p} K_{\mathrm{a}}$ estimation for $\mathbf{5}$ as in the case of $\mathbf{4}$ was not possible. There is a measurement for an analogous boranephosphonic acid with value 5.9 suggesting that the first $\mathrm{p} K_{\mathrm{a}}$ for boranephosphonates is much different to those of phosphonates and thiophosphonates. ${ }^{15}$ 


\section{Stability studies}

Having in hand the three new compounds $\mathbf{3}, \mathbf{4}$ and $\mathbf{5}$ and given the fact that these compounds can be used as building blocks for the corresponding pseudopeptide synthesis as well as for biological purposes, we decided to check their stability during storage at room temperature and under various $\mathrm{pH}$ values encountered either during synthesis or in several physiological environments. Thus, observation of the relative chemical stability and the different species that are formed in the $\mathrm{pH}$ range of 1-10 is essential. Samples were dissolved in buffers ( $\mathrm{pH} 1.0,4.0$, $5.0,8.0,10.0)$ at a concentration of approximately $0.1 \mathrm{M}$ and crude aliquots were directly analyzed by RP-HPLC. The stability (half life, $\mathrm{t}_{1 / 2}$ in days) of all the new compounds is presented in Table 2.

Table 2. Stability and behavior of phosphonic compounds in $\mathrm{pH}$ range 1-10

\begin{tabular}{lllllll}
\hline \multicolumn{7}{c}{$t_{1 / 2}(\mathrm{~d})$} \\
\hline compd & \multicolumn{1}{c}{ rt } & pH 1 & pH 4 & pH 5 & pH 8 & pH 10 \\
\hline $\mathbf{2}$ & stable $^{\mathrm{a}}$ & stable & stable & stable & stable & stable \\
$\mathbf{3}$ & 127 & 161 & 60 & 54 & 75 & 185 \\
$\mathbf{4}$ & 35 & 1 & 2 & 2 & 2 & 1 \\
$\mathbf{5}$ & 149 & 72 & 89 & 122 & 139 & 144 \\
\hline
\end{tabular}

a "stable" means no decomposition was detected after 4 months

Thiophosphonate $\mathbf{3}$ is relatively stable in storage at room temperature but decomposes faster in aqueous buffers especially in the medium $\mathrm{pH}$ ones giving as only product phosphonic acid $\mathbf{2}$ as confirmed by HPLC, ${ }^{31} \mathrm{P}$ NMR and mass spectrometry. Notable is its stability at alkaline $\mathrm{pH}$. Selenophosphonate $\mathbf{4}$ is quite unstable in all aqueous buffers and extensive deselenization occurs leading mainly to phosphonate $\mathbf{2}$ but also to phosphinic acid 1, as judged by mass spectrometry and ${ }^{31} \mathrm{P}$ NMR (19.3 ppm for $\mathbf{2}$ and $26.4 \mathrm{ppm}$ for $\mathbf{1}$ in $\mathrm{D}_{2} \mathrm{O}$ ). It is moderately stable in air, degrading over a period of 10 weeks with the obvious signs of red elemental selenium accompanied by the evolution of a malodorous gas.

Boranephosphonate 5 seems to be the most stable analog of 2. Decomposition of $\mathbf{5}$ at room temperature is slow, leading to $\mathrm{H}$-phosphinate $\mathbf{1}$. No phosphonate $\mathbf{2}$ was observed in all tested buffers as well as in the original sample.

\section{Conclusions}

Each of the individual steps in this synthetic approach has a literature precedent, but was applied for the first time to synthesize in high yield Cbz-protected phosphonic glycine structural analogs starting from the same precursor H-phosphinic acid. The identity of the novel compounds was confirmed by mass-spectrometry and elemental analysis and characterized by multinuclear $\left({ }^{1} \mathrm{H}\right.$, 
${ }^{13} \mathrm{C}$ and $\left.{ }^{31} \mathrm{P}\right)$ NMR and IR spectroscopy techniques as well as HPLC. The stability results indicate that boranephosphonic acids mainly, and thiophosphonic acids to a lesser extent, should be investigated every time a bioactive compound has been identified. In addition, they could serve as useful building blocks for boranephosphonic or thiophosphonic pseudopeptides synthesis which is still unexploited. Further studies on this class of compound are under way in our laboratory.

\section{Experimental Section}

General. All reactions were conducted under an argon atmosphere. Dry tetrahydrofuran (THF) and methylene chloride $\left(\mathrm{CH}_{2} \mathrm{Cl}_{2}\right)$ were obtained by distillation of commercially available solvents from $\mathrm{NaH}$. Purification of compounds by column chromatography was carried out on silica gel (70-230 mesh). In NMR measurements, $\mathrm{CDCl}_{3}, \mathrm{D}_{2} \mathrm{O}$ and DMSO- $d_{6}$ were used as solvents. ${ }^{1} \mathrm{H},{ }^{31} \mathrm{P}$, and ${ }^{13} \mathrm{C}$ NMR spectra were recorded on a $200 \mathrm{MHz}$ spectrometer. Proton and carbon chemical shifts are referenced to residual solvent. ${ }^{31} \mathrm{P}$ chemical shifts are reported on $\delta$ scale (in ppm) downfield from $85 \% \mathrm{H}_{3} \mathrm{PO}_{4}$. The following abbreviations were used to explain the NMR multiplicities: s) singlet, d) doublet, t) triplet, q) quartet, m) multiplet, br) broad. RPHPLC analyses were performed on a Hewlett Packard 1100 model (C18-Cromasil-RP, $5 \mu \mathrm{m}$ at a flow rate of $0.5 \mathrm{~mL} / \mathrm{min}$. Gradient: $t=0 \mathrm{~min}(0 \% \mathrm{~B}), t=10 \mathrm{~min}(25 \% \mathrm{~B}), t=45 \mathrm{~min}(75 \% \mathrm{~B}), t$ $=50 \min (100 \% \mathrm{~B}), t=52 \min (100 \% \mathrm{~B}), t=60 \min (40 \% \mathrm{~B}) /$ Solvent A: $10 \% \mathrm{CH}_{3} \mathrm{CN}, 90 \%$ $\mathrm{H}_{2} \mathrm{O}, 0.1 \%$ TFA. Solvent B: $90 \% \mathrm{CH}_{3} \mathrm{CN}, 10 \% \mathrm{H}_{2} \mathrm{O}, 0.09 \%$ TFA. Eluted peaks were detected by a UV detector at $254 \mathrm{~nm}$. ESI mass spectral analyses were performed on a Finnigan mass spectrometer (MSQ Surveyor) using direct sample injection. Negative or positive ion ESI spectra were acquired by adjusting the needle and cone voltages accordingly. IR spectra were recorded on a Thermo Nicolet IR200 FT-IR spectrometer.

$N$-Benzyloxycarbonylaminomethylphosphonic acid (2). A mixture of Cbz-aminomethyl phosphinic acid 1 (229 mg, $1 \mathrm{mmol})$, DMSO (70 $\mu \mathrm{L}, 1 \mathrm{mmol})$, and iodine $(1 \mathrm{mg})$ in $3 \mathrm{~mL}$ of THF was stirred under heating at $60{ }^{\circ} \mathrm{C}$ for $5 \mathrm{~h}$. The resulting mixture was evaporated to dryness in vacuo and the residue was triturated with diethyl ether. Filtration and washing with diethyl ether provided $2(227 \mathrm{mg}, 93 \%)$. IR (KBr) $\left(v_{\max } \mathrm{cm}^{-1}\right) 3350-2950(\mathrm{NH}, \mathrm{OH}), 1694(\mathrm{C}=\mathrm{O}), 1223$ $(\mathrm{P}=\mathrm{O}), 1030(\mathrm{P}-\mathrm{OH}) .{ }^{1} \mathrm{H}$ NMR $\left(200 \mathrm{MHz}, \mathrm{DMSO}-d_{6}\right) \delta 3.12\left(2 \mathrm{H}, \mathrm{bd}, \mathrm{CH}_{2} \mathrm{P}\right), 4.95\left(2 \mathrm{H} \mathrm{s}, \mathrm{CH}_{2} \mathrm{O}\right)$, $6.95(1 \mathrm{H}, \mathrm{bs}, \mathrm{NH}), 7.28(5 \mathrm{H}, \mathrm{s}$, arom. $), 8.40(2 \mathrm{H}, \mathrm{bs}, \mathrm{OH}) .{ }^{13} \mathrm{C} \mathrm{NMR}\left(50 \mathrm{MHz}, \mathrm{DMSO}-d_{6}\right) \delta 42.1$ $\left(\mathrm{d}, J_{P C}=94.3 \mathrm{~Hz}, \mathrm{CH}_{2} \mathrm{P}\right), 66.0\left(\mathrm{CH}_{2} \mathrm{O}\right), 128.3,128.9,137.7(6 \mathrm{C}$, arom $), 156.9(\mathrm{C}=\mathrm{O}) .{ }^{31} \mathrm{P}$ NMR $\left(81 \mathrm{MHz}, \mathrm{DMSO}-d_{6}\right) \delta 17.2$. ES-MS $m / z:(\mathrm{M}-\mathrm{H})=244.0$.

\section{Synthesis of $N$-Benzyloxycarbonylaminomethylphosphonic acid analogs 3 and 4 . General procedure}

To a mixture of 1 (229 mg, $1 \mathrm{mmol}$ ), and sulfur powder (96 mg, $3 \mathrm{mmol}$ ) for $\mathbf{3}$ or selenium (237 $\mathrm{mg}, 3 \mathrm{mmol})$ for $4 \mathrm{in} \mathrm{CH}_{2} \mathrm{Cl}_{2}(4 \mathrm{~mL})$ at $0{ }^{\circ} \mathrm{C}$ under argon was added dropwise BSA (1.24 mL, 5 
$\mathrm{mmol})$. The mixture was allowed to warm to room temperature and stirred for $1 \mathrm{~h}$. After addition of $\mathrm{MeOH}(4 \mathrm{~mL})$, the mixture was stirred for $15 \mathrm{~min}$, filtered over Celite and then concentrated in vacuo. The residue was partitioned between ethyl acetate and water. The organic layer was washed with $\mathrm{HCl} 1 \mathrm{~N}$, water, dried over $\mathrm{Na}_{2} \mathrm{SO}_{4}$ and concentrated in vacuo affording 3 (234 mg, $90 \%)$ or 4 (267 mg, $87 \%)$ as glassy solids.

$N$-Benzyloxycarbonylaminomethylthiophosphonic acid (3) $\mathrm{IR}(\mathrm{KBr})\left(v_{\max }, \mathrm{cm}^{-1}\right) 3350-2950$ $(\mathrm{NH}, \mathrm{OH}), 1682(\mathrm{C}=\mathrm{O}), 1045(\mathrm{P}-\mathrm{OH}), 632(\mathrm{P}=\mathrm{S}) .{ }^{1} \mathrm{H}$ NMR $\left(200 \mathrm{MHz}, \mathrm{CDCl}_{3}\right) \delta 3.68(2 \mathrm{H}, \mathrm{bd}$, $\left.\mathrm{CH}_{2} \mathrm{P}\right), 5.04\left(2 \mathrm{H}, \mathrm{s}, \mathrm{CH}_{2} \mathrm{O}\right), 5.77(1 \mathrm{H}, \mathrm{bs}, \mathrm{NH}), 7.27(5 \mathrm{H}, \mathrm{s}, \mathrm{arom}), 9.78(2 \mathrm{H}, \mathrm{bs}, \mathrm{OH}) .{ }^{13} \mathrm{C} \mathrm{NMR}$ $\left(50 \mathrm{MHz}, \mathrm{CDCl}_{3}\right) \delta 46.3\left(\mathrm{~d}, J_{P C}=101.2 \mathrm{~Hz}, \mathrm{CH}_{2} \mathrm{P}\right), 66.6\left(\mathrm{CH}_{2} \mathrm{O}\right), 127.7,127.8,128.2,136.9(6 \mathrm{C}$, arom), $156.8(\mathrm{C}=\mathrm{O}) .{ }^{31} \mathrm{P}$ NMR $\left(81 \mathrm{MHz}, \mathrm{CDCl}_{3}\right) \delta$ 77.4. ES-MS $\mathrm{m} / z:(\mathrm{M}-\mathrm{H})=260.2$. Anal. Calcd. For $\mathrm{C}_{9} \mathrm{H}_{12} \mathrm{NO}_{4} \mathrm{PS}$ (261.23): C, 41.38; H, 4.63; N, 5.36\%. Found: C, 41.51; H, 4.30; N, $5.29 \%$.

$N$-Benzyloxycarbonylaminomethylselenophosphonic acid (4) $\mathrm{IR}(\mathrm{KBr})\left(v_{\max } \mathrm{cm}^{-1}\right) 3350-2950$ $(\mathrm{NH}, \mathrm{OH}), 1684(\mathrm{C}=\mathrm{O}), 1045(\mathrm{P}-\mathrm{OH}), 570(\mathrm{P}=\mathrm{Se}) .{ }^{1} \mathrm{H}$ NMR $\left(200 \mathrm{MHz}, \mathrm{CDCl}_{3}\right) \delta 3.72(2 \mathrm{H}, \mathrm{bd}$, $\left.\mathrm{CH}_{2} \mathrm{P}\right), 5.01\left(2 \mathrm{H}, \mathrm{s}, \mathrm{CH}_{2} \mathrm{O}\right), 5.81(1 \mathrm{H}, \mathrm{bs}, \mathrm{NH}), 7.27(5 \mathrm{H}, \mathrm{s}$, arom $), 10.17(2 \mathrm{H}, \mathrm{bs}, \mathrm{OH}) .{ }^{13} \mathrm{C}$ NMR $\left(50 \mathrm{MHz}, \mathrm{CDCl}_{3}\right) \delta 49.9\left(\mathrm{~d}, J_{P C}=96.0 \mathrm{~Hz}, \mathrm{CH}_{2} \mathrm{P}\right), 67.5\left(\mathrm{CH}_{2} \mathrm{O}\right), 128.2,128.4,128.7,136.1(6 \mathrm{C}$, arom), $157.4(\mathrm{C}=\mathrm{O}) .{ }^{31} \mathrm{P} \mathrm{NMR}\left(81 \mathrm{MHz}, \mathrm{CDCl}_{3}\right) \delta$ 76.2. ES-MS $m / z:(\mathrm{M}-\mathrm{H})=308.1$. Anal. Calcd. For $\mathrm{C}_{9} \mathrm{H}_{12} \mathrm{NO}_{4} \mathrm{PSe}$ (308.97): C, 35.08; H, 3.93; N, 4.55\%. Found: C, 35.28; H, 3.75; N, $4.60 \%$.

$N$-Benzyloxycarbonylaminomethylboranephosphonic acid (5). A solution of 1 (229 mg, 1 $\mathrm{mmol})$ in anhydrous THF (4 mL) was treated with BSA $(1.24 \mathrm{~mL}, 5 \mathrm{mmol})$ at room temperature for $1 \mathrm{~h}$, under argon. A solution of $\mathrm{BH}_{3} \cdot \mathrm{Me}_{2} \mathrm{~S}(2.0 \mathrm{M}$ in THF, $1.0 \mathrm{~mL}, 2 \mathrm{mmol})$ was then added at room temperature, and the resulting mixture stirred for $1 \mathrm{~h}$. After addition of $\mathrm{MeOH}(4 \mathrm{~mL})$, the mixture was stirred for $15 \mathrm{~min}$ and then concentrated in vacuo. The residue was partitioned between $\mathrm{CHCl}_{3}$ and $\mathrm{H}_{2} \mathrm{O}$ and the aqueous layer was concentrated in vacuo, affording the desired product $5(208 \mathrm{mg}, 91 \%)$ as a colorless gel. IR $(\mathrm{KBr})\left(v_{\max } \mathrm{cm}^{-1}\right) 3350-2950(\mathrm{NH}, \mathrm{OH}), 2358$ $\left(\mathrm{BH}_{3}\right), 1681(\mathrm{C}=\mathrm{O}), 1047(\mathrm{P}-\mathrm{OH}), 780(\mathrm{P}-\mathrm{B}) .{ }^{1} \mathrm{H}$ NMR $\left(200 \mathrm{MHz}, \mathrm{D}_{2} \mathrm{O}\right) \delta 1.70\left(3 \mathrm{H}, \mathrm{bs}, \mathrm{BH}_{3}\right)$, $3.15\left(2 \mathrm{H}, \mathrm{bs}, \mathrm{CH}_{2} \mathrm{P}\right), 4.69\left(2 \mathrm{H}, \mathrm{s}, \mathrm{CH}_{2} \mathrm{O}\right), 6.97\left(5 \mathrm{H}, \mathrm{s}\right.$, arom). ${ }^{13} \mathrm{C} \mathrm{NMR}\left(50 \mathrm{MHz}, \mathrm{D}_{2} \mathrm{O}\right) \delta 41.0$ $\left(\mathrm{d}, J_{P C}=61.3 \mathrm{~Hz}, \mathrm{CH}_{2} \mathrm{P}\right), 67.2\left(\mathrm{CH}_{2} \mathrm{O}\right), 127.7,128.3,128.7,136.2(6 \mathrm{C}$, arom $), 158.0(\mathrm{C}=\mathrm{O}) .{ }^{31} \mathrm{P}$ $\operatorname{NMR}\left(81 \mathrm{MHz}, \mathrm{D}_{2} \mathrm{O}\right) \delta 117.6\left(\mathrm{~d}, J_{P B}=135.6 \mathrm{~Hz}\right)$. ES-MS $m / z:(\mathrm{M}-\mathrm{H})=242.3$. Anal. Calcd. For $\mathrm{C}_{9} \mathrm{H}_{15} \mathrm{BNO}_{4} \mathrm{P}$ (243.08): C, 44.48; H, 6.22; N, 5.76\%. Found: C, 44.26; H, 6.41; N, 5.43\%.

\section{References and Notes}

1. (a) Kafarski, P.; Lejczak, B. Curr. Med. Chem.-Anti-cancer agents 2001, 1, 301. (b) Metcalf' W.W.; van der Donk, W. A. Annu. Rev. Biochem. 2009, 78, 65.

2. Chruszcz-Lipska, K.; Zborowski, K. K.; Podstawka-Proniewicz,E.; Liu,S.; Xu,Y.; Proniewicz, L.M. J. Mol. Struct. 2011, 986, 49.

3. Manzenrieder, F.; Frank, A. O.; Kessler, H. Angew. Chem. Int. Ed. 2008, 47, 2608. 
4. Orsini, F.; Sello, G.; Sisti, M. Curr. Med. Chem. 2010, 17, 264.

5. Yiotakis, A.; Matziari, M.; Makaritis, A.; Georgiadis, D.; Dive, V. Curr. Org. Chem. 2004, $8,1135$.

6. Swierczek, K.; Pandey, A. S.; Peters, J. W.; Hengge, A. C. J. Med. Chem. 2003, 46, 3703.

7. Barral, K.; Priet, S.; Sire, J.; Neyts, J.; Balzarini, J.; Canard, B.; Alvarez, K. J. Med. Chem. 2006, 49, 7799.

8. Vassiliou S.; Grabowiecka A.; Kosikowska P.; Yiotakis A.; Kafarski P.; Berlicki L. J. Med. Chem., 2008, 51, 5736.

9. Albouy, D.; Brun, A.; Munoz, A.; Etemad-Moghadam, G. J. Org. Chem. 1998, 63, 7223.

10. SPARC Performs Automated Reasoning in Chemistry. http://ibmlc2.chem.uga.edu/sparc/.

11. Yields are given for the compounds isolated after workup or trituration. Column chromatography is possible for compounds 3, 4, and 5 using $\mathrm{CH}_{2} \mathrm{Cl}_{2}-\mathrm{MeOH}-\mathrm{AcOH}$ : 9-1-0.5 as eluent in order to obtain analytically pure samples without especially affecting the yield.

12. (a) Kimura, T.; Murai, T. J. Org. Chem., 2005, 70, 952; (b) Hua, G.; Zhang, Q.; Li, Y.; Slawin, A. M.-Z.; Woollins, J. D. Tetrahedron, 2009, 65, 6074.

13. Moroder, L. J. Pept. Sci. 2005, 11, 187.

14. Odom, J. D.; Kalasinsky, V. F.; Duric, J. R. J. Mol. Struct., 1975, 24, 139.

15. Belabassi, Y.; Gushwa, A. F.; Richards, A. F.; Montchamp, J.-L. Phosphorus, Sulfur Silicon. 2008, 183, 2214. 